\title{
Efficiency Improvement of Induction Motor Through Altered Design
}

\author{
S.Usha, C.Subramani, Adisha Raman, Manali Bhaduri, M. Arun Noyal Doss, Raghav Puri
}

\begin{abstract}
Three phase squirrel cage induction motors are widely used in industries and hence in this paper we have aimed to increase a motor's efficiency by augmenting its cooling process. The motor chosen was of $3 \mathrm{HP}$ rating. Motor structure was altered to improve its efficiency and its performance characteristics were analysed to compare with the conventional motor design. A dynamic model was constructed in Matlab Simulink to observe the changes in speed and phase currents on varying load. After successful dynamic modelling, the motor is simulated using Motor Solver and various performance parameters are observed and monitored. This is followed by improving the efficiency by using Aluminium as material for the stator housing and rotor bar and end ring. Silicon steel is used for stator back iron. High cost of Aluminium used to design the stator casing is compensated by the nullification of high maintenance and operational costs.
\end{abstract}

\section{INTRODUCTION}

Induction motors are widely used in industrial applications because of features such as self-starting property, simple construction, robustness, economical, reliability and less maintenance. Some of the applications of 3 phase induction motors include lifts, cranes, hoists, traction etc. The modified motor designed in this paper is specific to applications that require high torque at high speed.

The main limiting factor in the fine operation and life time of an electrical machine which can be operated continuously on load is the temperature of the various circuit elements that constitute the machine. In these motors if the efficiency can be increased by just a few percentages, it will still have a major impact on the energy consumption and operation. Hence in this paper, a new casing for the stator is designed using Aluminium as opposed to the conventional cast iron, stator back iron is made of Silicon steel and rotor bar and end rings are made of $61 \%$ Alminium IACS to increase efficiency. As the conductivity of aluminium is poor as compared to copper, 61\% aluminium is used[2]. Although [3] discusses that increase in silicon in the core leads to decreased

Revised Version Manuscript Received on 10, September 2019.

S.Usha, Department of Electrical and Electronics Engineering, SRM Institute of Science and Technology, Kattankulathur, Chennai, Tamilnadu, India.

C.Subramani, Department of Electrical and Electronics Engineering, SRM Institute of Science and Technology, Kattankulathur, Chennai, Tamilnadu, India.

Adisha Raman, Department of Electrical and Electronics Engineering, SRM Institute of Science and Technology, Kattankulathur, Chennai, Tamilnadu, India.

Manali Bhaduri, Department of Electrical and Electronics Engineering, SRM Institute of Science and Technology, Kattankulathur, Chennai, Tamilnadu, India.

M. Arun Noyal Doss, Department of Electrical and Electronics Engineering, SRM Institute of Science and Technology, Kattankulathur, Chennai, Tamilnadu, India.

Raghav Puri, Department of Electrical and Electronics Engineering, SRM Institute of Science and Technology, Kattankulathur, Chennai, Tamilnadu, India. saturation flux density which in turn decreases efficiency, we found that by changing the stator back iron material to silicon steel, the efficiency increases. In addition to this, stator slot liner material is changed from epoxy resin to Nomex 430 for higher shear adhesion property.

The technique used for dynamic modelling of the conventional machine is stationary stator reference frame method. MotorSolve has been used to alter the motor structure.

The results in [4] show, that for the same frame size, mechanical or electrical loading must be increased to increase torque which in turn leads to greater copper losses and lower efficiency. As the rotor of the modified motor is made up of Aluminium, the losses have reduced and the efficiency has increased. A novel approach of including permanent magnet in the rotor was explored in [5] for high efficiency remanufacturing, however due to the cost of permanent magnet only a low efficiency approach could be explored.

Efficiency improvement with the help of structural alteration was explored in [6] as well by incrementing stack length of prototype motors however significant increase in efficiency could not be achieved as the motors were already built for premium efficiency ratings.

The technique used for dynamic modelling of the conventional machine is stationary stator reference frame method. After successful dynamic modelling of the conventional motor, its physical parameters are calculated using [7]. On calculation of the physical parameters of the motor, the values are entered in Motor Solver and its performance characteristics are observed and monitored. Following this, the aforementioned structural changes are made to the motor and simulated. The performance characteristics of the modified motor have been shown and comparisons of different behavioural characteristics have been tabulated for better understanding.

\section{ANALYSIS OF EXISTING MOTOR}

\section{A. Dynamic Modelling Of Motor}

A $3 \mathrm{HP}$ motor was chosen. The name plate details of the motor as shown in Table I. Dynamic modelling techniques are based on reference frame theory. Reference frame theory is widely used as it reduces the complexity of differential equations that describe the machine model by transforming variables to either rotor or stator side. There are two models in this theory: synchronous rotating reference frame and

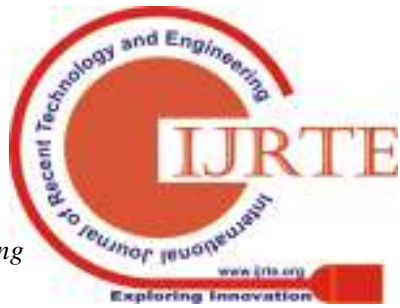


stationary stator reference frame.

TABLE I

NAME PLATE DETAILS OF 3HP MOTOR

\begin{tabular}{|l|l|}
\hline Rated speed & $1440 \mathrm{rpm}$ \\
\hline Rated voltage & $415 \mathrm{~V}, 3$ phase supply \\
\hline Rated Current & $4.5 \mathrm{~A}$ \\
\hline Frequency & $50 \mathrm{~Hz}$ \\
\hline Insulation & F class \\
\hline Make & Crompton Greaves \\
\hline Rated power & $2.2 \mathrm{~kW}$ \\
\hline
\end{tabular}

We have used stationary stator reference frame method to make the thermal model of the induction motor as it offers easy computation because there is no involvement of PI regulator tuning and linearization of small signal model as opposed to synchronous rotating reference frame. This dynamic model was constructed in Matlab Simulink[4] with the help of the mathematical model of the motor described the following equations and matrices.

$$
\begin{aligned}
& V s \alpha=R s * I s \alpha+L s * \frac{d I s \alpha}{d t}+L m * \frac{d I r \alpha}{d t} \\
& V s \beta=R s * I s \beta+L s * \frac{d I s \beta}{d t}+\operatorname{Lm} * \frac{d I r \beta}{d t} \\
& V r \alpha=R r * I s \alpha+L r * \frac{d I r \alpha}{d t}+L m * \frac{d I s \alpha}{d t}+\omega r * L r \\
& \quad * I r \beta+\omega r * L m * I s \beta \\
& V r \beta=R r * I r \beta+L r \frac{d I r \beta}{d t}+L m \frac{d I s \beta}{d t}-\omega r * L m * \operatorname{Ir} \alpha
\end{aligned}
$$

\begin{tabular}{|l|l|l|l|l|l|l|l|l|}
\hline & $I s \alpha$ & $I s \beta$ & $\operatorname{Ir} \alpha$ & $\operatorname{Ir} \beta$ & $\frac{d I s \alpha}{d t}$ & $\frac{d I s \beta}{d t}$ & $\frac{d I r}{d t}$ & $\frac{d I r}{d t}$ \\
\hline$V s \alpha$ & $\mathrm{Rs}$ & 0 & 0 & 0 & $\mathrm{Ls}$ & 0 & $\mathrm{Lm}$ & 0 \\
\hline$V s \beta$ & 0 & $\mathrm{Rs}$ & 0 & 0 & 0 & $\mathrm{Ls}$ & 0 & $\mathrm{Lm}$ \\
\hline$V r \alpha$ & 0 & $\omega r L m$ & $\mathrm{Rr}$ & $\omega r L r$ & $\mathrm{Lm}$ & 0 & $\mathrm{Lr}$ & 0 \\
\hline$V r \beta$ & - & 0 & $-\omega r L r$ & $\mathrm{Rr}$ & 0 & $\mathrm{Lm}$ & 0 & $\mathrm{Lr}$ \\
& $\omega r L m$ & & & & & & & \\
\hline
\end{tabular}

$$
\frac{d I}{d t}[L]=-[R][I]+[V]
$$

$\left[\begin{array}{cccc}L s & 0 & L m & 0 \\ 0 & L s & 0 & L m \\ L m & 0 & L r & 0 \\ 0 & L m & 0 & L r\end{array}\right] \quad \frac{d}{d t} \quad\left[\begin{array}{c}I s \alpha \\ I s \beta \\ I r \alpha \\ \operatorname{Ir} \beta\end{array}\right]$

$\left[\begin{array}{cccc}R s & 0 & 0 & 0 \\ 0 & R s & 0 & 0 \\ 0 & \omega r L m & R r & \omega r L r \\ -\omega r L m & 0 & -\omega r L r & R r\end{array}\right] *\left[\begin{array}{c}I s \alpha \\ I s \beta \\ I r \alpha \\ I r \beta\end{array}\right]+$ $\left[\begin{array}{c}V s \alpha \\ V s \beta \\ 0 \\ 0\end{array}\right]$

Simulation circuit :

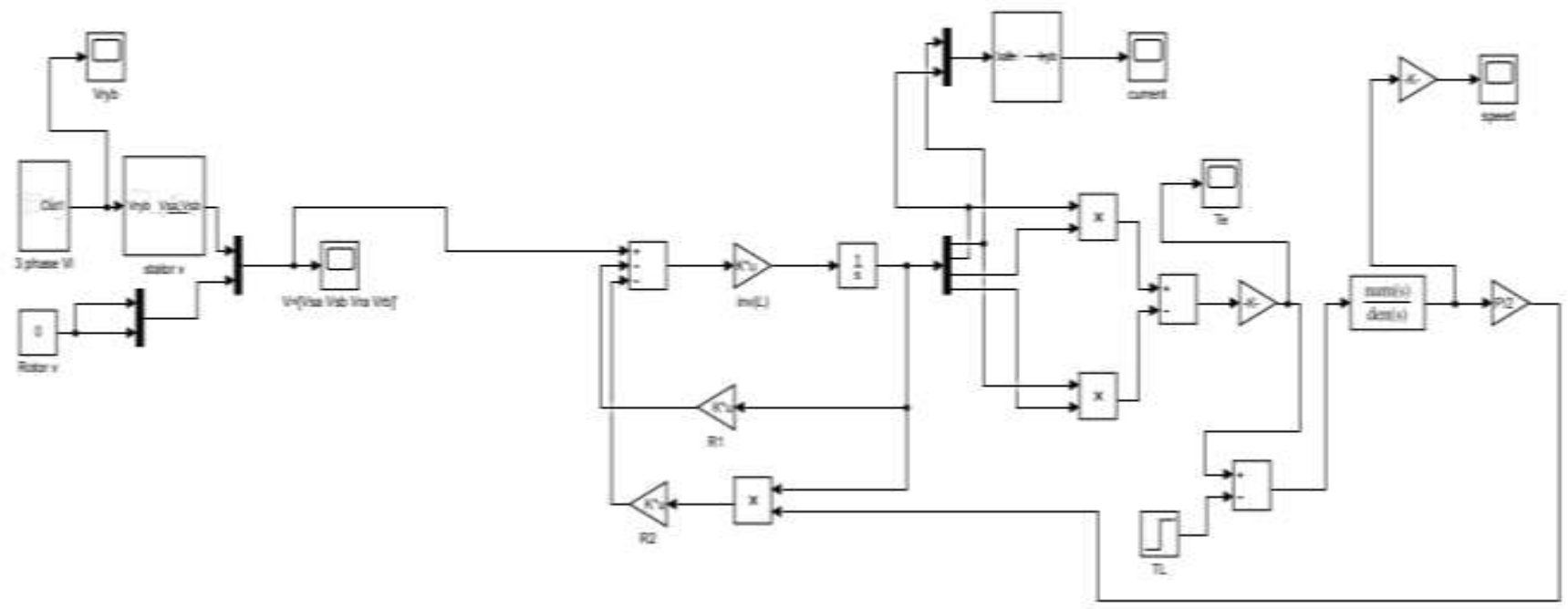

Fig. 1. MATLAB SIMULATION CIRCUIT 


\section{Model Parameters:}

The following parameters were used for model initialization in Matlab Simulink.

Line voltage, $\mathrm{V}_{\mathrm{L}}=415 \mathrm{~V}$

Power frequency, $\mathrm{pf}=50 \mathrm{~Hz}$

Stator resistance, $\mathrm{R}_{\mathrm{s}}=3.45 \Omega$

Rotor resistance, $\mathrm{R}_{\mathrm{r}}=3.6141 \Omega$

Stator inductance, $\mathrm{L}_{\mathrm{s}}=0.3246 \mathrm{H}$

Rotor inductance, $\mathrm{L}_{\mathrm{e}}=0.3252 \mathrm{H}$

Mutual inductance, $\mathrm{L}_{\mathrm{m}}=0.3117 \mathrm{H}$

Moment of inertia, $\mathrm{J}=0.02 \mathrm{~kg} \mathrm{~m}^{2}$

Friction coefficient, $\mathrm{B}=0.001$

No. of poles, $\mathrm{P}=4$

$\mathrm{L}=\left[\mathrm{L}_{\mathrm{s}}, 0, \mathrm{~L}_{\mathrm{m}}, 0\right.$;

$0, \mathrm{~L}_{\mathrm{s}}, 0, \mathrm{~L}_{\mathrm{m}}$;

$\mathrm{L}_{\mathrm{m}}, 0, \mathrm{~L}_{\mathrm{r}}, 0$;

$\left.0, \mathrm{~L}_{\mathrm{m}}, 0, \mathrm{~L}_{\mathrm{r}} ;\right]$

$\mathrm{R} 1=\left[\mathrm{R}_{\mathrm{s}}, 0,0,0\right.$;

$0, \mathrm{R}_{\mathrm{s}}, 0,0$

$0,0, \mathrm{R}_{\mathrm{r}}, 0$;

$0,0,0, \mathrm{R}_{\mathrm{r}}$;]

$\mathrm{R} 2=[0,0,0,0$;

$$
\begin{aligned}
& 0,0,0,0 ; \\
& 0, \mathrm{~L}_{\mathrm{m}}, 0, \mathrm{~L}_{\mathrm{r}} ; \\
& \left.-\mathrm{L}_{\mathrm{m}}, 0,-\mathrm{L}_{\mathrm{r}}, 0 ;\right]
\end{aligned}
$$

Where $\mathrm{L}$ is the inductance matrix, $\mathrm{R}$ is the resistance matrix which is expressed as the sum of two separate matrices R1 and R2.

\section{Experimental Setups And Results:}

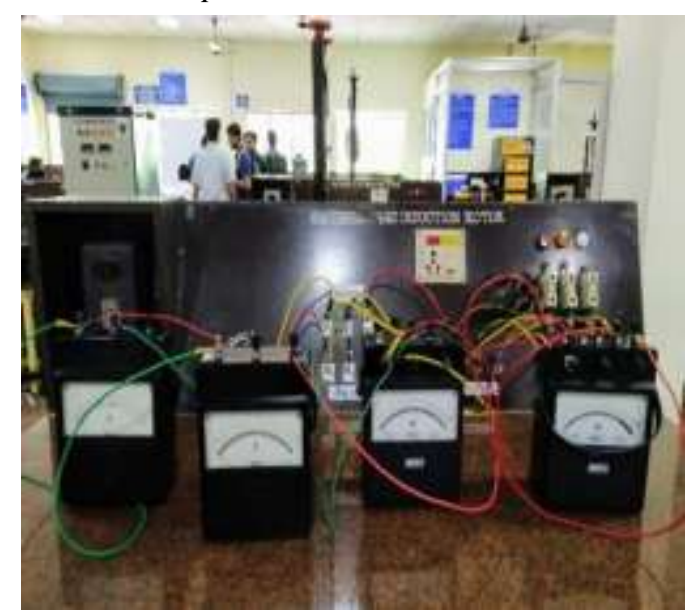

(a)

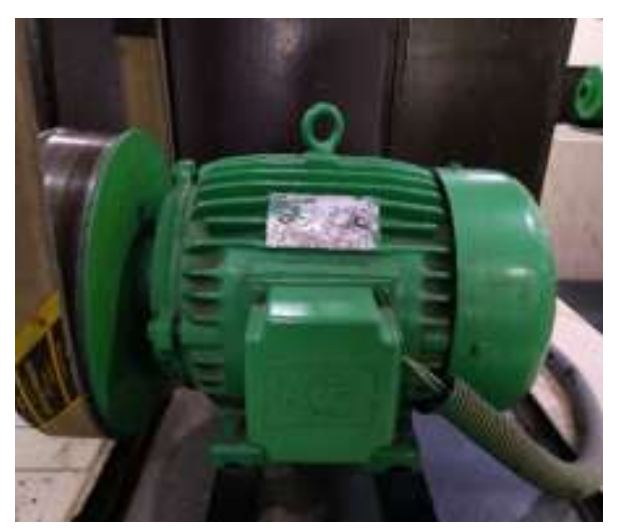

(b)

Fig. 2. (a) Setup for load test. (b) Motor used in the paper.
In order to obtain model parameters various tests such as load test, no load test, blocked rotor test were performed.

The parameters measured during these tested are given below.

\begin{tabular}{|c|c|c|}
\hline $\begin{array}{cc}\text { No } & \text { load } \\
\text { Voltage }(V) & \end{array}$ & $\begin{array}{cc}\text { No } & \text { load } \\
\text { Current(A) } & \end{array}$ & $\begin{array}{c}\text { No } \\
\text { Power(W) }\end{array}$ \\
\hline 415 & 2.25 & 304 \\
\hline
\end{tabular}

TABLE II

NO LOAD TEST PARAMETERS

Table III

BLOCKED ROTOR VOLTAGE

\begin{tabular}{|c|c|c|}
\hline $\begin{array}{c}\text { Blocked rotor } \\
\text { Voltage(V) }\end{array}$ & $\begin{array}{r}\text { Blocked rotor } \\
\text { current(A) }\end{array}$ & Power(W) \\
\hline 142 & 4.5 & 640 \\
\hline
\end{tabular}

TABLE IV

LOAD TEST MEASURED VALUES

\begin{tabular}{|l|l|l|l|l|}
\hline $\begin{array}{l}\text { Current( } \\
\text { A) }\end{array}$ & $\begin{array}{l}\text { Speed(rp } \\
\mathrm{m})\end{array}$ & $\begin{array}{l}\text { Load(Nm } \\
\text { ) }\end{array}$ & $\begin{array}{l}\text { Output } \\
\text { Power(W } \\
)\end{array}$ & $\begin{array}{l}\text { Efficienc } \\
\mathrm{y}\end{array}$ \\
\hline 2.2 & 1486 & 0.88 & 137.39 & 17.17 \\
\hline 2.75 & 1478 & 2.83 & 437 & 36.416 \\
\hline 3 & 1470 & 3.53 & 543.3 & 37.73 \\
\hline 3.45 & 1462 & 4.77 & 729 & 45.594 \\
\hline
\end{tabular}

Results Of Simulation

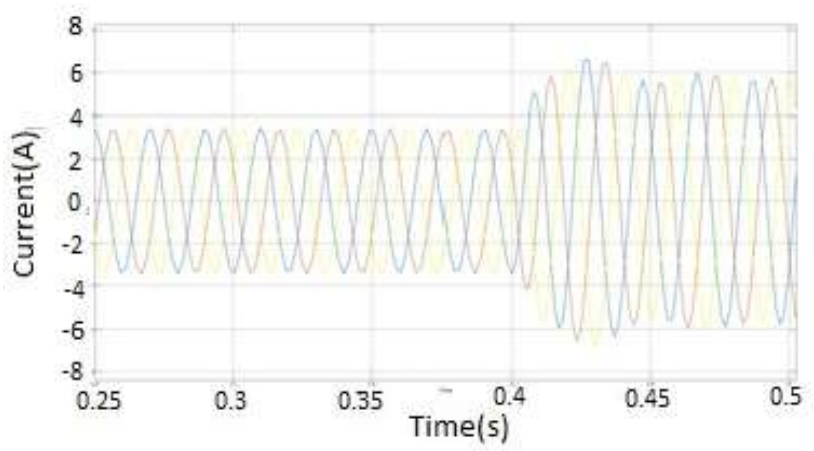

(a)

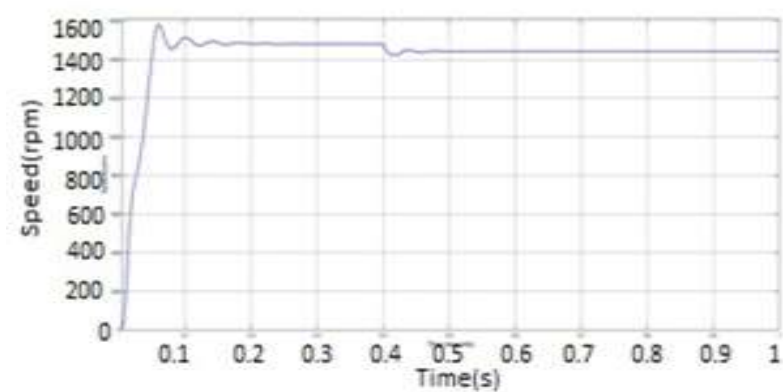

(b)

Fig. 3. (a) Current vs time. (b) Speed vs time.

The motor was given a step signal for changing the load torque. Initially a torque of $20 \mathrm{Nm}$ was applied and then it was increased to $40 \mathrm{Nm}$. All the three phase currents are plotted against time and it was observed that for a constant load torque at $20 \mathrm{Nm}$ the current was $3 \mathrm{~A}$ and after 0.4 second

Published By: 
when the torque is changed to $40 \mathrm{Nm}$ the time, the current increases with oscillations which settle down after a few milliseconds to a value of $6 \mathrm{~A}$. Thus on increase of load torque, the amount of current drawn by the motor increases.

Similarly, when speed vs time curve was plotted it was observed that initially the speed curve had many oscillations due to start of the motor which settled down after a few milliseconds and reached a steady value upon application of $20 \mathrm{Nm}$ torque. Upon increase of the torque to $40 \mathrm{Nm}$, the speed curve oscillates and reaches a value lower to the previous value. Thus as the load torque of the motor increases the speed of the motor decreases.

\section{B. Modelling Of Motor In Motorsolve}

The following parameters were calculated from [7] and used in MotorSolve[8].

TABLE V

DIMENSIONS OF MOTOR USED IN MOTORSOLVE

\begin{tabular}{|c|c|c|}
\hline Parameter & Value & Dimension \\
\hline $\begin{array}{ll}\begin{array}{l}\text { Stator } \\
\text { diameter }\end{array} & \text { outer } \\
\end{array}$ & 245 & $\mathrm{~mm}$ \\
\hline Length of air gap & 0.454 & $\mathrm{~mm}$ \\
\hline $\begin{array}{l}\begin{array}{l}\text { No. of stator } \\
\text { slots }\end{array} \\
\end{array}$ & 36 & \\
\hline $\begin{array}{l}\text { Outer diameter } \\
\text { of rotor }\end{array}$ & 143 & $\mathrm{~mm}$ \\
\hline $\begin{array}{l}\text { Inner diameter of } \\
\text { rotor }\end{array}$ & 97.02 & $\mathrm{~mm}$ \\
\hline $\begin{array}{ll}\begin{array}{l}\text { Stator } \\
\text { diameter }\end{array} & \text { inner } \\
\end{array}$ & 143 & $\mathrm{~mm}$ \\
\hline $\begin{array}{l}\text { Depth of rotor } \\
\text { core }\end{array}$ & 23.9 & $\mathrm{~mm}$ \\
\hline $\begin{array}{l}\text { Depth of stator } \\
\text { core }\end{array}$ & 33.8 & $\mathrm{~mm}$ \\
\hline $\begin{array}{l}\text { Depth of stator } \\
\text { slots }\end{array}$ & 16.9 & $\mathrm{~mm}$ \\
\hline $\begin{array}{l}\text { Housing } \\
\text { thickness }\end{array}$ & 14.2 & $\mathrm{~mm}$ \\
\hline $\begin{array}{l}\text { Left bearing } \\
\text { width }\end{array}$ & 28.5 & $\mathrm{~mm}$ \\
\hline $\begin{array}{l}\text { Right bearing } \\
\text { width }\end{array}$ & 28.5 & $\mathrm{~mm}$ \\
\hline Rotor slots & 19 & \\
\hline
\end{tabular}

Performance curves of the conventional motor:

Supply voltage:

During the entire course of the simulation of the motor in MotorSolve, the supply voltage was kept constant as shown in Fig. 4.

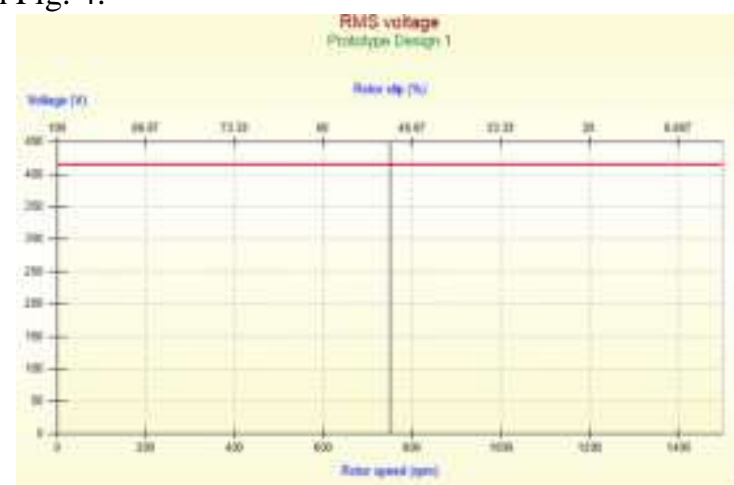

Fig. 4. Supply voltage vs Rotor speed for conventional motor.
Efficiency:

The overall efficiency of the conventional motor was observed to be $38.9 \%$.

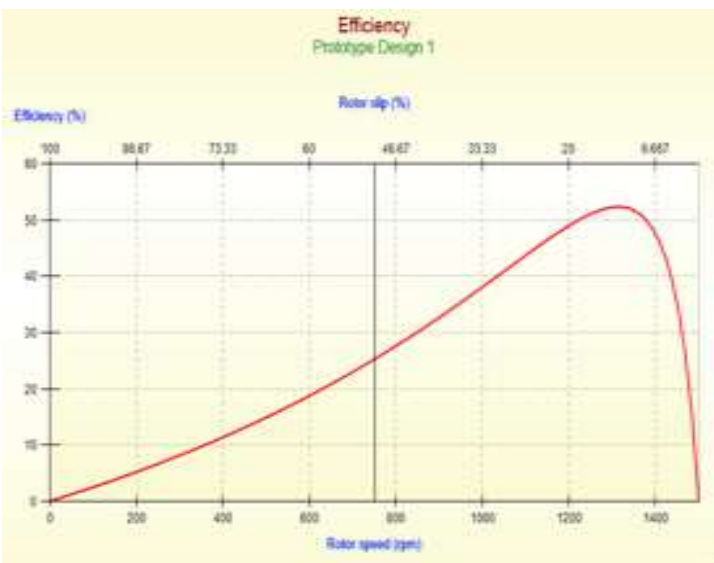

Fig. 5. Efficiency vs rotor speed curve of conventional motor.

The maximum efficiency of the motor was observed to be $52.4 \%$ at a speed of $1304 \mathrm{rpm}$.

Torque:

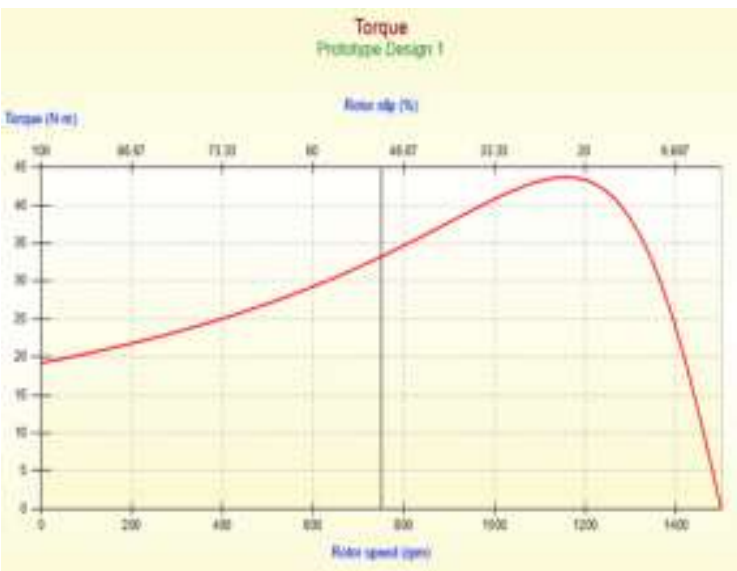

Fig. 6. Torque vs Rotor speed curve for conventional motor.

The maximum torque was observed to be $43.8 \mathrm{Nm}$ at rotor speed of 1136rpm.

Flux Distribution :

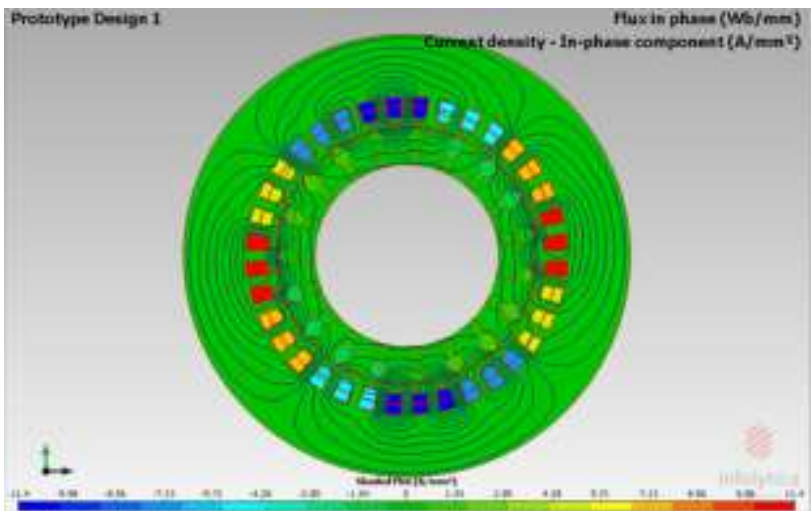

Fig. 7. Flux distribution of conventional motor.

Published By:

Blue Eyes Intelligence Engineering

\& Sciences Publication 


\section{PERFORMANCE ANALYSIS OF MODIFIED MOTOR}

In order to improve the motor performance, the housing of the motor which was initially made up of CR10: Cold rolled steel is replaced by Aluminium 61\% IACS. Aluminium has good corrosion resistance due to the formation of an oxide layer on the metal on reaction with different materials. Steel casings have to be painted from time to time to avoid corrosion. The cost of this regular maintenance can be saved by using Aluminium as the casing material even though the material cost of Aluminum is higher. In addition to this property it is more flexible than steel thus aiding in design of casing ridges. Due to technological advancements Aluminum extrusions can be designed easily than the tedious process of casting iron.

$61 \%$ Aluminium IACS is used for the Rotor bars and end ring. Usage of Aluminium decreases losses that occur in various parts of the machine and increase cooling. This has been used instead of steel laminations. Aluminium is lighter in weight.

Carpenter: Silicon steel has been used for stator back iron material instead of M-19-Ga Steel. This particular metal has good electrical resistivity and also is vital to decrease eddy current and hysteresis loss. Nomex 430 has been used instead of epoxy resin for stator slot liner material as it has higher shear adhesion than epoxy and is relatively inexpensive.

This motor can be used for applications requiring high torque at high speed and good efficiency at high speed regions for example in crashing plants and in locomotives.

The supply voltage used was the same as for the conventional motor i.e. $415 \mathrm{~V}$. Fig. 7 shows the flux distribution of the modified motor.

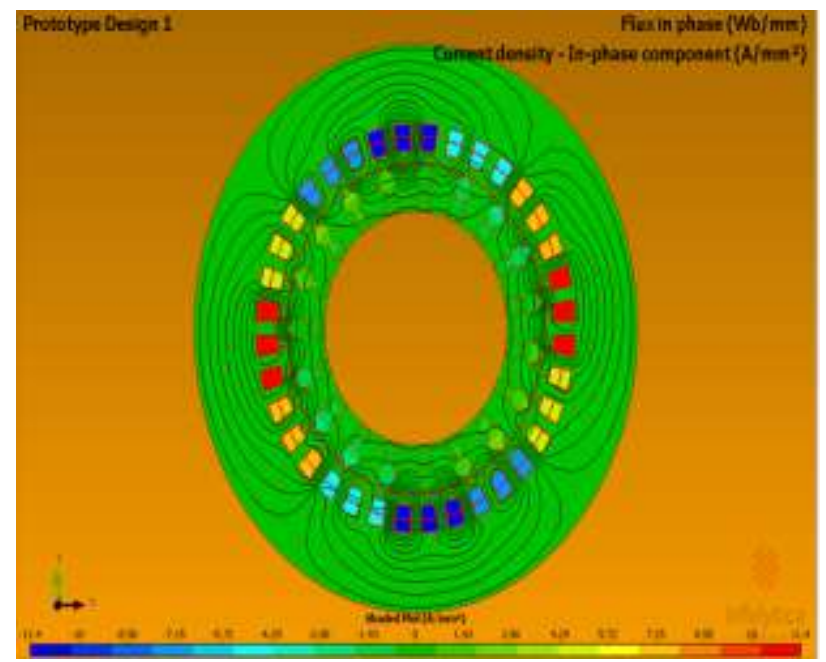

Fig. 8. Flux distribution and current density of altered motor.

\section{COMPARISON OF CONVENTIONAL MOTOR AND MODIFIED RESULTS}

After the material changes were made to the motor the following simulation results were obtained. The overall efficiency of the motor was increased by $5 \%$. The power of the motor increased from $3 \mathrm{HP}$ to $3.5 \mathrm{HP}$. The overall losses were observed to have decreased. Various parameters such as torque, efficiency, losses, energy and coenergy were analyzed.

\section{TABLE VI}

COMPARISON OF EFFICIENCY OF MOTOR AT DIFFERENT SPEEDS (CONVENTIONAL VS MODIFIED)

\begin{tabular}{|l|l|l|l|l|}
\hline S.no & Speed & $\begin{array}{l}\text { Conventio } \\
\text { nal motor } \\
\text { efficiency }\end{array}$ & $\begin{array}{l}\text { Modified } \\
\text { motor } \\
\text { efficiency }\end{array}$ & $\begin{array}{l}\text { Percentage } \\
\text { improveme } \\
\text { nt }\end{array}$ \\
\hline 1 & 200 & 5.18 & 5.16 & \\
\hline 2 & 400 & 11.4 & 11.7 & \\
\hline 3 & 600 & 18.8 & 19. & \\
\hline 4 & 800 & 27.6 & 28.2 & \\
\hline 5 & 1000 & 38.2 & 38.6 & \\
\hline 6 & 1200 & 49.1 & 49.8 & 1.4 \\
\hline 7 & 1250 & 51.1 & 51.6 & 0.9 \\
\hline 8 & 1300 & 52.3 & 53.8 & 2.9 \\
\hline 9 & 1350 & 51.8 & 54.5 & 5.2 \\
\hline 10 & 1400 & 47.7 & 51.7 & 8.4 \\
\hline
\end{tabular}

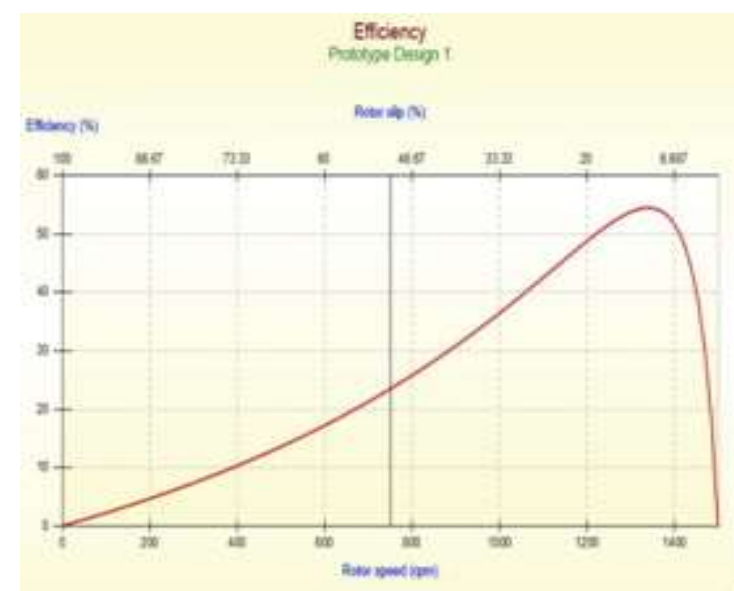

Fig. 9. Efficiency curve of altered motor.

The overall efficiency of the motor has been increased by $5 \%$. The conventional motor had an efficiency of $38.9 \%$ whereas the new motor has an efficiency of $43.9 \%$. The maximum efficiency of the motor was observed to be $54.5 \%$ at a speed of 1350rpm. From the table above it can be inferred that the modified motor performs well in the high speed region. In low speed and medium speed region the efficiencies of both the motors are very similar.

\section{TABLE VII}

COMPARISON OF TORQUE AT DIFFERENT SPEEDS (CONVENTIONAL VS MODIFIED)

\begin{tabular}{|c|c|c|c|c|}
\hline S.no & $\begin{array}{c}\text { Rotor } \\
\text { speed }\end{array}$ & $\begin{array}{c}\text { Torque in } \\
\text { conventional } \\
\text { motor }\end{array}$ & $\begin{array}{c}\text { Torque } \\
\text { in modified } \\
\text { motor }\end{array}$ & Slip \\
\hline 1 & 200 & 21.8 & 22.7 & 86.7 \\
\hline 2 & 400 & 25.1 & 25.2 & 73.3 \\
\hline 3 & 600 & 29.3 & 29.3 & 60 \\
\hline 4 & 800 & 34.7 & 35.1 & 46.7 \\
\hline 5 & 1000 & 40.9 & 41.2 & 33.3 \\
\hline 6 & 1200 & 43.4 & 44.2 & 20 \\
\hline 7 & 1300 & 38.2 & 41.9 & 13.4 \\
\hline 8 & 1400 & 23.9 & 28.1 & 6.71 \\
\hline 9 & 1440 & 15.2 & 18.1 & 4.02 \\
\hline
\end{tabular}




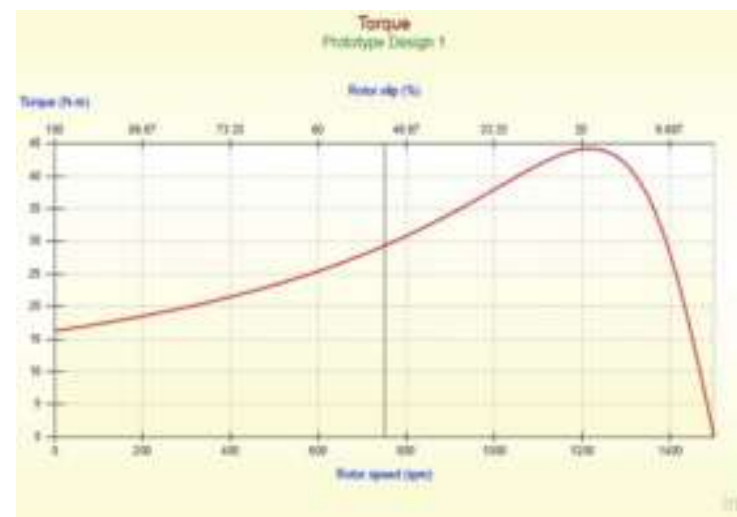

Fig. 10. Torque curve of altered motor.

From Table VII it can be observed that the modified motor has a higher torque value compared to conventional motor when operating in high slip region for the same speed as that of conventional motor. The maximum torque was observed to be $44.3 \mathrm{Nm}$ at rotor speed of $1222 \mathrm{rpm}$. The motor is suitable for high speed region applications that require good torque and efficiency.

Motion analysis is done for final design verification by performing a full time-stepping non-linear finite element analysis simulation for all types of operating conditions of the two motors using loss, energy and coenergy as result parameters was carried out and the following results were obtained.

TABLE VIII

COMPARISON OF LOSS, ENERGY AND

COENERGY OF THE CONVENTIONAL AND MODIFIED MOTOR

\begin{tabular}{|c|c|c|c|c|c|c|c|}
\hline & & \multicolumn{3}{|c|}{$\begin{array}{l}\text { CONVENTIONA } \\
\mathrm{L}\end{array}$} & \multicolumn{3}{|c|}{ MODIFIED } \\
\hline $\begin{array}{l}\text { ce } \\
\text { phas } \\
\mathrm{e} \\
\text { angl } \\
\mathrm{e}\left(^{\circ}\right)\end{array}$ & $\begin{array}{l}\text { Roto } \\
\text { r } \\
\text { angl } \\
e\left(^{\circ}\right)\end{array}$ & Loss & $\begin{array}{l}\text { Ene } \\
\text { rgy( } \\
\text { J) }\end{array}$ & $\begin{array}{l}\text { Coener } \\
\mathrm{gy}(\mathrm{J})\end{array}$ & $\begin{array}{l}\text { Los } \\
\mathrm{s}\end{array}$ & $\begin{array}{l}\text { Energ } \\
\mathrm{y}(\mathrm{J})\end{array}$ & $\begin{array}{l}\text { Coener } \\
\operatorname{gy}(\mathrm{J})\end{array}$ \\
\hline 60 & 202 & 6.88 & 76 & 98.2 & $\begin{array}{l}6.4 \\
4\end{array}$ & 76.3 & 101 \\
\hline 120 & 231 & 7.17 & $\begin{array}{l}79 . \\
4\end{array}$ & 103 & $\begin{array}{l}6.7 \\
2 \\
\end{array}$ & 79.7 & 106 \\
\hline 180 & 260 & 7.14 & $\begin{array}{l}81 . \\
5\end{array}$ & 106 & $\begin{array}{l}6.5 \\
2\end{array}$ & 81.6 & 109 \\
\hline 240 & 288 & 6.65 & $\begin{array}{l}79 . \\
6\end{array}$ & 104 & $\begin{array}{l}6.1 \\
8 \\
\end{array}$ & 79.9 & 107 \\
\hline 300 & 317 & 6.72 & $\begin{array}{l}76 . \\
9\end{array}$ & 99.5 & $\begin{array}{l}6.3 \\
9\end{array}$ & 77.4 & 103 \\
\hline 360 & 346 & 6.91 & $\begin{array}{l}75 . \\
8\end{array}$ & 96.1 & $\begin{array}{l}6.4 \\
1 \\
\end{array}$ & 76.4 & 98.5 \\
\hline 420 & 374 & 6.67 & 76 & 96.7 & $\begin{array}{l}6.3 \\
3\end{array}$ & 76.4 & 99.4 \\
\hline 480 & 404 & 6.75 & $\begin{array}{l}77 . \\
1 \\
\end{array}$ & 99 & $\begin{array}{l}6.1 \\
7 \\
\end{array}$ & 77 & 102 \\
\hline 540 & 435 & 6.78 & $\begin{array}{l}77 . \\
9 \\
\end{array}$ & 100 & $\begin{array}{l}6.4 \\
8 \\
\end{array}$ & 77.5 & 106 \\
\hline 600 & 461 & 7.01 & $\begin{array}{l}77 . \\
4\end{array}$ & 98.4 & $\begin{array}{l}6.6 \\
1 \\
\end{array}$ & 77.6 & 101 \\
\hline 660 & 490 & 6.64 & $\begin{array}{l}75 . \\
9\end{array}$ & 96.5 & $\begin{array}{l}6.1 \\
5\end{array}$ & 76.1 & 99.3 \\
\hline 720 & 518 & 6.25 & $\begin{array}{l}74 . \\
5\end{array}$ & 95.4 & $\begin{array}{l}5.7 \\
3 \\
\end{array}$ & 74.9 & 97.6 \\
\hline
\end{tabular}

As coenergy and energy both relate to the electromagnetic torque of the motor, it is desirable to have higher values of the same. In the modified motor, coenergy is high for the same outer dimensions, which indicates higher power density of the machine and lower losses. This has been successfully obtained from the modified motor as per tabulated results.

TABLE IX

TEMPERATURES AT DIFFERENT POINTS IN THE MOTOR (UNIT ${ }^{\circ} \mathrm{C}$ )

\begin{tabular}{|l|l|l|}
\hline Part & $\begin{array}{l}\text { Conventional } \\
\text { motor }\end{array}$ & Modified motor \\
\hline Bar & 109 & 110 \\
\hline Rotor back iron & 109 & 110 \\
\hline Rotor tooth & 109 & 110 \\
\hline Stator back iron & 110 & 112 \\
\hline Stator coil side & 122 & 128 \\
\hline $\begin{array}{l}\text { Stator coil side } \\
\text { slotmate }\end{array}$ & 124 & 129 \\
\hline Stator tooth & 113 & 115 \\
\hline
\end{tabular}

From Table IX it can be observed that the altered motor is capable of operating at higher temperatures as compared to the conventional motor which accounts for its versatile use.

\section{CONCLUSION}

In this paper performance of a conventional induction motor was improved using by altering the structure of the motor using Aluminum as material for casing and rotor bar and end ring material, Silicon steel as stator back iron material and Nomex 430 as stator slot liner material. Although the initial costs of the motor are increased, it is compensated by low maintenance costs. The modified motor is light in weight and has better efficiency in high speed regions. The overall efficiency of the motor was increased by $5 \%$ which is significant in an induction motor. Efficiency and performance of motor can be further increased by intricate design of the casing. The modified motor is suitable for crashing plants, locomotives, large capacity exhaust fans etc.

\section{REFERENCES}

1. "Simulation and Research of Induction Motor Considering Iron Loss in Stationary Reference Frame", Yin Jun ; Lu Xiaoli ; Wei Yunbing ; Cui Guangzhao , 2010 International Conference on Computing, Control and Industrial Engineering

2. "Increasing the efficiency of induction motors", Michael Braun, Electrical Electronics Insulation Conference and Electrical Manufacturing \& Coil Winding Conference, 1993. Proceedings., Chicago '93 EEIC/ICWA Exposition.

3. "Loss Distribution of Three-Phase Induction Motor and BLDC Motor According to Core Materials and Operating", S. O. Kwon ; J. J. Lee ; B. H. Lee ; J. H. Kim ; K. H. Ha ; J. P. Hong, IEEE Transactions on Magnetics ( Volume: 45 , Issue: 10 , Oct. 2009 ) 
4. "Efficiency Map Comparison of Induction and Synchronous Reluctance Motors", Anton Rassolkin, Hamidreza Heidari, Ants Kallaste, 2019 26th International Workshop on Electric Drives: Improvement in Efficiency of Electric Drives (IWED)

5. "High efficiency remanufacturing of induction motors with interior permanent-magnet rotors and synchronous-reluctance rotors", Chengrui Li ; Dianguo $\mathrm{Xu}$; Gaolin Wang, 2017 IEEE Transportation Electrification Conference and Expo, Asia-Pacific (ITEC Asia-Pacific)

6. "The Incremental Design Efficiency Improvement of Commercially Manufactured Induction Motors", IEEE Transactions on Industry Applications ( Volume: 49, Issue: 6 , Nov.-Dec. 2013 )

7. "A Course in Electrical Machine Design", A. K. Sawhney, Chakrabarti, Publisher: Dhanpat Rai \& Co. Pvt. Ltd.

8. "Electrical Machine Design with MotorSolve and Matlab", V. Rajini, V. S. Nagarajan, Publisher: Pearson. 